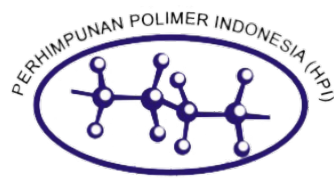

\title{
A Review on Current Developments and Prospects in Biomass - Based Bioplastics
}

\author{
H. Kurnia Adia, A. Matteo ${ }^{a}$, H. Al Hijria, M. Chalid ${ }^{a}+$ \\ Bioplastics are among the current type of plastics that are aggressively being developed worldwide. Some of the reasons \\ supporting its developments are due to its recyclable and also biodegradable properties which are promising in reducing \\ plastic wastes while can also still be modified in order to meet the required mechanical and/or thermal properties in \\ contrast to the petrol or fuel-based counterpart, not to mention bioplastic manufacturing is also prospective in business. \\ This paper will shortly review on the current developments as well as prospects regarding advancements in several \\ bioplastics types of research and studies. The review's highlights include characterization, mechanical properties, thermal \\ properties, and business prospects of bioplastics.
}

Received

10 October 2018

Received in revised form

Accepted

28 December 2018

Published

31 December 2018

Bioplastik termasuk ke dalam jenis plastik yang saat ini sedang dikembangkan secara pesat. Beberapa alasan yang mendukung dalam perkembangannya adalah karena bioplastik dapat didaur ulang dan dapat terurai secara alami sehingga menjanjikan untuk dapat mengurangi sampah plastik dan juga dapat dimodifikasi untuk menyesuaikan sifat mekanis dan termalnya berdasarkan dengan aplikasinya. Hal ini berlawanan dengan plastik yang berasal dari minyak bumi, apalagi manufaktur bioplastik juga memiliki prospek dalam segi bisnis. Literatur ini akan mengulas secara singkat mengenai perkembangan serta prospek terkini terkait kemajuan-kemajuan dalam penelitian dan studi-studi beberapa jenis bioplastik. Pokok bahasan dalam ulasan ini mencakup karakterisasi, sifat mekanis, sifat termal, dan prospek bisnis terkait bioplastik.

DOI: $10.37889 / \mathrm{mpi}$.2018.21.2.4

Keywords: Bioplastic, business prospects, characterization, mechanical properties, thermal properties.

\section{Introduction}

Plastic is a type of polymer material which commonly came from the by-products of oil productions, and thus are usually called petrol-based plastics or petrochemical plastics. Several common examples of petrochemical plastics are polyethylene terephthalate (PET), high density polyethylene (HDPE), low density polyethylene (LDPE), and polypropylene (PP) with their primary usage mainly for packaging. However, due to their characteristic of having a considerably long time to start degrading (32 years after soil burial for polyethylene (PE) film) ${ }^{1}$ which proves to be a major environmental problem, it inevitably become a serious threat. It was due to this concern that many alternatives have been put forward in order to reduce the environmental pollution. One of the most feasible alternative against this problem is the utilization of bio-based plastics or bioplastics.

Bioplastic is a type of plastic made from renewable biomass sources and so it comes with a special characteristic to degrade without causing any harmful effect to its nature. Historically, the concept of bioplastic has already been put forward since 1920s and has been produced for commercial use since 1970s, but higher production cost compared to the petrochemical counterparts has also always been the main problem in mass producing the bioplastics.

\footnotetext{
a. Department of Metallurgy and Materials Engineering, Universitas Indonesia, UI Depok New Campus, Depok 16424, West Java, Indonesia

+ Corresponding author: chalid@metal.ui.ac.id.
}

Despite difficulties in entering both commodities and market, advances in bioplastics have been made in the last few years - several consumer goods and retail companies have been utilizing several percentages of their packaging materials replaced with renewable resources. ${ }^{2}$ Based on a literature study conducted by Z. Kuruppalil, an environmentally friendly plastic is a plastic that is categorized as "green plastic" which shows one or more of these characteristics: biodegradable, having renewable sources, and environmentally friendly when processed. Additionally, there are actually some biodegradable petrochemical plastics, with one of the examples being polylactic acid (PLA). Another study conducted by S. Spierling, et al., bioplastics possess a circular economy system which indicates a very promising future development potential for sustainable business prospects. ${ }^{3}$ This paper will shortly review on several performances regarding the characterization, mechanical properties, thermal properties, and business prospects of bioplastics that are made from several biomass sources: starch, cellulose, gluten, and other protein sources such as soy protein, and pea protein.

\section{Physical Properties}

1. Starch - based Bioplastic

Starch is well known for its ability as a raw material especially for the production of green bioplastics. Being an organic material, it easily degrades compared to the petrochemical counterparts. The main components of starch are amylose and amylopectin. Amylose is a linear poly- 
mer arranged of almost $\alpha-(1-4)$ - linked glucose residues with a molecular weight $(\mathrm{Mw})$ around $105-106 \mathrm{~g} \mathrm{~mol}^{-1}$. At a higher level of organization, the arrangement of crystalline polymorphs inside starch differs due to the type of the plant's organ. The crystalline structures are classified into A - type and B - type. ${ }^{4}$

A study on bioplastic based on amylose - only (AO) starch with Btype and $\mathrm{Vh}$ - type crystallinity was conducted by $\mathrm{D}$. Sagnelli, et al. whom also utilized control starch with A - type crystallinity. ${ }^{4}$ Based on the study, it was reported that after extrusion process the weight average molar mass of the control starch decreased from $2.15 \times 10^{8} \mathrm{~g} \mathrm{~mol}^{-1}$ to $1.06 \times 10^{8} \mathrm{~g} \mathrm{~mol}^{-1}$ while also experienced decrease in dispersity by 1.9 fold. However, despite also experiencing decrease in weight average molar mass and dispersity, AO starch experienced less decrease from $9.1 \times 10^{6} \mathrm{~g} \mathrm{~mol}^{-1}$ to $6.3 \times 10^{6} \mathrm{~g} \mathrm{~mol}^{-1}$ and dispersity decrease by only $1 / 3$ fold compared to the control starch due to only minor depolymerization during extrusion. The phenomenon caused the decrease in sensitivity of chain scission of the $\mathrm{AO}$ starch.

J. Gonzalez - Gutierrez, et al. conducted a study on bioplastics based on mixture of wheat gluten with mixtures of glycerol and corn and potato starch. ${ }^{5}$ Based on the study, it was reported that addition of potato starch cause a slight decrease in elongation at break from $235.1 \%$ to $163.5 \%$ and tensile strength from 0.52 MPa to $0.32 \mathrm{MPa}$. However, the addition of corn starch into the wheat gluten bioplastics made a drop in elongation at break from $235.1 \%$ to $70.8 \%$ and tensile strength from $0.52 \mathrm{MPa}$ to $0.13 \mathrm{MPa}$. This phenomenon suggested that the properties of the wheat gluten matrix controlled the mechanical properties when potato starch was added, but the opposite works when corn starch was added into the wheat gluten matrix.

\section{Cellulose - based Bioplastic}

Several studies regarding the utilization of cellulose as hybrid in several types of polymers have been reported. ${ }^{6-7}$ A study on the utilization of cellulose as the main material in manufacturing was also conducted by L. Chen, et al., ${ }^{8}$ who stated that cellulose cannot be directly utilized to manufacture bioplastic due to the presence of intra and interchain hydrogen bonding. However, another study conducted by Zhang, et al. proved that bioplastic manufactured from cellulose hydrogel is possible. $^{9}$

According to the study conducted by L. Chen, et.al, ${ }^{8}$ the synthesis cellulose bioplastic with the utilization of grapheme aerogel (GA) resulted in the formation of bioplastic with low crystallinity caused by the hindrance of cellulose chains movements by the three - dimensional GA. The phenomenon caused the formation of GA inclusion, resulting in the decrease of the intensity.

\section{Gluten - based Bioplastic}

Gluten is a type of protein that can be integrated as a bioplastic. One of the most popular gluten based bioplastic stems from wheat gluten, because of the abundance of the raw material required. Gluten is a cohesive, visco-elastic proteinaceous material with strong thermoplastic properties which is isolated from wheat. Furthermore, the extraction of such material is relatively easy, in which it only requires the washing of wheat dough to remove the starch, since it is soluble, whereas gluten is insoluble in water. The composition of wheat gluten is divided into 2 parts according to their solubility in alcohol-water solution, which are the soluble gliadins (low-molecular-weight, single-chain, compact and globular-shaped proteins with a molecular weight of 20-50 kDa) and the insoluble glutenins (high-molecular-weight of up to 106 Da protein fraction comprised of aggregated proteins linked by interchain disulfide bond. Other than that, Wheat gluten is a large extended polypeptide polymer without globular structure..$^{10}$

A study on gluten - based bioplastics was conducted by D. Gómez - Martínez, et al. regarding the effect of several modifying agents towards its controlled - release on agricultural nutrient $(\mathrm{KCl})$ as well as hydrophilic properties. ${ }^{11}$ Based on the study, it was reported that wheat gluten bioplastic modified with mixture of $16.5 \%$ polyethylene glycol (PEG) with molecular weight of $4000 \mathrm{~g} \mathrm{~mol}^{-1}, 3 \%$ of octanoic acid, and $10 \%$ water resulted in the highest concentration of $\mathrm{KCl}$ released by the bioplastic. The effect of addition of PEG 4000 initially made the bioplastic had a poor ability to control the $\mathrm{KCl}$ release, although it has a considerably good flecural and swelling properties. According to the study, $\mathrm{KCl}$ release depends on the addition of acid as an additive. The utilization of octanoic acid as the additive made the bioplastic have the fastest release rate of polar salt caused by the hindrance of $\mathrm{KCl}$ diffusion due to significant decrease in bioplastic water uptake, which formed a polymer matrix with low polar salt affinity.

A study on the effect in adding polysaccharides from locust bean gum (LBG), methyl cellulose (MC), and carboxymethyl cellulose (CMC) to the hydrophilic properties of gluten - based bioplastic was conducted by L. S. Zárate - Ramírez. ${ }^{12}$ According to the study, it was reported that the value of water uptake capacity and loss of soluble matters were all similar for all variables, with about $40 \mathrm{wt} \%$ of water absorption after $2 \mathrm{~h}$ of testing to around $70 \mathrm{wt} \%$ after $24 \mathrm{~h}$ of testing, with the usage of LBG polysaccharide resulting in the lowest water uptake after $24 \mathrm{~h}$, and the highest loss in soluble matter. The loss of soluble matters in all variables was probably due to the some polysaccharide molecules as well as plasticizer was still soluble after processing. The amount of soluble matter loss in all of the variables is also similar of around $23 w t \%$, which is also similar to the amount of glycerol initially added in order to form the bioplastic.

\section{Other Proteins - based Bioplastic}

There are other types of protein used as a base to make bioplastic other that starch gluten. One of them is protein isolate. Generally, protein isolate is a high protein content $(>90 \% \mathrm{wt} / \mathrm{wt}$ ) extracted from organic materials such as whey, pea, and soy. The process itself includes separating the protein from the lactose, fat, and gluten contained in the organic materials mentioned before. Since protein isolate is mostly made of protein, the chemical structure of the isolate is generally a protein chain with peptide bonds, which are basically chains of amino acids. Therefore, it is usually known as a poIypeptide. ${ }^{13}$

A study in determining the pea protein isolate (PPI) physical properties for the development of bioplastics was conducted by V. Perez. ${ }^{14}$ Based on the study, it was reported that the rate of water absorption was considerably fast and the capacity of water uptake was very high reaching above $100 \%$ which indicates that the protein system of the PPI has a hydrophilic characteristic. The absorption reached its maximum values within $2 \mathrm{~h}$ immersion testing, and no significant increase after $24 \mathrm{~h}$ of immersion. The study utilized two variables regarding the ratio of PPI with glycerol $(G)$ as plasticizer, and change in the ratio didn't show any significant change in water uptake and may be caused by the tendency of the water in filling the voids formed by glycerol migration which may also hydrate the 
hydrophilic area of protein surfaces. The study also measures the transparency of the crystal formed in the bioplastic, and in this case the decrease in the amount of PPI content increases the transparency because the polymer crystal became more crystalline and opaque compared to the variable with less PPI content according to the transmittance index. The concept of transparency in a biomass - based polymer however, is not the same as the petrochemical counterparts; the transparency of biopolymer also gives effect mainly to heat - induced secondary reactions such as Maillard reactions which associated with colour changes and thus, also gives effect to the transparency of the polymer.

M. Félix, et al. conducted a study on the development of albumen protein (AP) and soy protein isolate (SPI) based bioplastic with addition of glycerol (GL) as plasticizer. ${ }^{15}$ Based on the study, it was reported that increase in AP content resulted in the decrease of water absorption of up to about half of the variable without albumen content which was caused due to differences in the conditions of thermomechanical processing, with one of the example being an increase in molding pressure leading to significant reduction in water absorption. The soluble matter loss for the $100 \%$ albumen content, and no SPI content shows $40 \%$ loss, whereas other variables with any SPI content especially in $20 \%$ content shows slight increase in soluble matter loss. This phenomenon was due to the less association of the protein to the network structure of the polymer, and also because of highly hydrophilic nature of the GL due to the fact that all of the variables contain $40 \% \mathrm{GL}$. The result of the transmittance index of the variables shows an increasing trend which corresponds with the increase in albumen content as well as increase in transparency, indicating that the increase in albumen content also makes the polymer crystal more crystalline.

\section{Mechanical Properties}

\section{Starch - based Bioplastic}

The study conducted by D. Sagnelli, et al. regarding the physical properties of amylose only (AO) starch bioplastic was already discussed in the previous chapter. The mechanical properties of the same material was also reported in the study. The amylose only starch bioplastic with 5 minutes of melting time (AO5) showed the highest ductility, tensile strength, as well as impact strength and elongation at break compared to other variables with 10 (AO10) and 20 minutes of melting time (AO20), and also in the controlled variable (without melting time). ${ }^{4}$ The occurrence of the phenomenon was due to the chain scission of the starch during the melting procedure. If compared with the controlled variable, the elongation at break for $\mathrm{AO} 5$ is twice as high as the value of the controlled variable, and the tensile stress at break is 6 times higher than the value of the controlled variable.

Another study conducted by J. Gonzalez - Gutierrez, et al. regarding the physical properties of bioplastics synthesized from wheat gluten with corn starch and potato starch was also already discuses in the previous chapter. The tensile strength and the elongation at break of the bioplastic have a decreasing trend with the increase of starches up to $30 w t \%$ content, and was more evident with the presence of potato starch $^{5}$ which indicated that the potato starches granules acted as a stress concentration inside the bioplastic matrix, resulting in the decrease of tensile strength and lower elongation at break. The pheno- menon was due to heterogeneities inside the matrix created by the potato starches granules. Nevertheless, when compared to the Polylactic acid/Starch (PLA/Starch) commercial sample, the bioplastic with 10wt\% content of corn starch performs similar tensile strength, and a considerably higher elongation at break.

\section{Cellulose - based Bioplastic}

The study conducted by $\mathrm{Q}$. Wang, et al. regarding the physical properties of cellulose bioplastic synthesized by utilizing graphene aerogel (GA) was already discussed in the previous chapter. The mechanical properties of the same material was also reported in the study. The hardness of the $\mathrm{GA} /$ cellulose bioplastics has a significantly higher value compared to the hardness of pure cellulose bioplastic. ${ }^{8}$ The phenomenon was caused by a good interfacial bonding between the GA and the cellulose bioplastic matrix proven by the SEM images of the study. The young's modulus value which represents stiffness of the GA/cellulose bioplastic was lower than that of the pure cellulose counterpart, indicating that the $\mathrm{GA} /$ cellulose bioplastics are more ductile.

The compression strength of the $\mathrm{GA} /$ cellulose bioplastic in the same study was also represented with the stress - strain curve of the bioplastic which suggests 3 conditions of deformation. When the load applied is equal to $10 \%$ of the ultimate tensile strength, the cell wall bends which corresponds to nearly linear elastic regime. Once the applied load increases to between $10 \%$ and $50 \%$, the cellulose cell wall buckles which corresponds to stress plateau. Lastly, when the load surpasses $50 \%$, densification occurs due to sudden stress increasing region. The phenomenon was caused by the filling of GA pores with cellulose plastic, which then triggers the covering of cell wall that reinforces the sliding graphene sheets.

\section{Gluten - based Bioplastic}

Study on gluten bioplastic conducted by D. Gómez - Martínez, et al. regarding the physical properties was already discussed in the previous chapter. According to the study, values of the complex modulus of the bioplastic increase after addition of Polyethylene Glycol (PEG) as plasticizer at temperatures below $80^{\circ} \mathrm{C}$, as well as after the increase of the PEG molecular weight from $200 \mathrm{~g} \mathrm{~mol}^{-1}$ to $4000 \mathrm{~g}$ mol-1 $^{-1}$, but experiences decrease in complex modulus. ${ }^{11}$ This phenomenon was caused by macroscopic phase separation on the bioplastic plasticized by PEG 8000 , which results in complex modulus significant decrease.

Another study conducted by L. S. Zárate - Ramírez, et al. regarding the physical properties of bioplastic synthesized from wheat gluten mixed with polysaccharides was already discussed in the previous chapter. According to the study, the addition of polysaccharides increases the value of tensile strength, elongation at break as well as impact strength. Further increase in the mechanical properties was also evident in the variables utilizing Methyl Cellulose (MC) as well as Carboxymethyl Cellulose (CMC) based polysaccharides..$^{12}$ The occurrence of the phenomenon was due to the fact that both $\mathrm{MC}$ and $\mathrm{CMC}$ polysaccharides are more compatible inside the bioplastic matrix which then alter the hydrogen bonds, thus preventing strong bonds formation after material thermo - moulding process.

\section{Other Proteins - based Bioplastic}

The study on characteristic of pea protein isolate (PPI) for bioplastic application by V. Perez, et al. was already discussed in the previous chapter. According to the study, both tensile strength and tensile 
modulus value increases with the increase of PPI content. However, the elongation at break is higher for less PPI content. ${ }^{14}$ The phenomenon was caused by the better ability of the bioplastic to absorb energy before break with the increase of the protein.

A study conducted by M. Félix, et al. regarding the physical properties of albumen protein (AP) and soy protein isolate (SPI) was already discussed in the previous chapter. According to the study, when compared to LDPE, all variable utilizing AP and SPI contents in bioplastic have lower value of tensile strength. It was also reported that the increase of AP content to $50 \%$ in the bioplastic yields increase in the tensile strength value, however at $100 \%$ AP content there was no significant change for the tensile strength. ${ }^{15}$ The phenomenon suggested that AP - based bioplastic still have a better tensile strength than the SPI - based counterpart.

\section{Thermal Properties}

\section{Starch - based Bioplastic}

The physical properties and mechanical properties of the starch - based bioplastics study by D. Sagnelli, et al. was already discussed in previous chapters. According to the study, it was shown that all of the Amylose Only (AO) starch bioplastic variables except for the controlled variables showed similar glass transition temperature $(\mathrm{Tg})$ of $25^{\circ} \mathrm{C}$, and another peak occurred at around $100^{\circ} \mathrm{C}$, as shown by Dynamic Mechanical Analyzer (DMA) testing. ${ }^{4}$ The occurrence of the phenomenon might be due to sample dehydration caused by heating scan, and the occurrence of rubbery plateau in all of the extruded samples also support the possibility of sample dehydration.

A study by J. Gonzalez - Gutierrez, et al. on protein/starch - based bioplastic also discussed its thermal properties. According to the study, albumen and gluten - based bioplastics did not show any melting process during heating, on the other hand LDPE experienced the most detererioration in complex modulus as the temperature rose until it approached the melting point of around $120^{\circ} \mathrm{C} .{ }^{5}$ The phenomenon might be caused by the existence of different thermo-mechanical responses which depends on the variations of mixtures of compounds. Due to the thermal performances of albumen in the study, it was also mixed with potato and corn starch to be synthesized as bioplastics in the study.

\section{Cellulose - based Bioplastic}

The study on physical properties and mechanical properties of cellulose - based bioplastics conducted by L. Chen, et al. was already discussed in previous chapters. The thermal conductivity of the same type of bioplastic as the thermal properties was also discussed in the study. In determining the thermal conductivity of the samples, the study utilized an infrared thermal camera and used a laser gun as the heat source. In order to heat the sample on top, a laser shot from the laser gun is needed.

According to the result of the study, the temperature distribution of cellulose bioplastic is inferior compared to pure graphene aerogel (GA) and cellulose/GA composite. ${ }^{8}$ The most uniform temperature distribution is also evident in pure GA sample. The occurrence of the phenomenon was due to the good thermal conductivity of pure graphene aerogel. The addition of GA inside the cellulose bioplastic thus enhances the thermal conductivity of the composite. The good thermal conductivity of the graphene aerogel was caused by the presence of stacked graphene layers, which offers axial conduction thermal paths.

\section{Gluten - based Bioplastic}

Previous chapters already discussed the physical properties and mechanical properties regarding the study of gluten - based bioplastic by D. Gómez - Martínez, et al. According to the study, torque overshoot appeared in samples with PEG200, PEG600, and PEG4000 mixtures after 2-3 minutes after mixing, meanwhile the sample with PEG8000 mixtures showed torque overshoot after 6 minutes of mixing. ${ }^{11}$ Torque overshoot is a phenomenon where several torque peaks appear frequently in the torque curves initial segments as shown in a dynamometer. ${ }^{19}$ The occurrence of the torque overshoot phenomenon was due to the significant evolution of gluten structure during mixing, ended with final torque decay which was due to consistent change from powder or plasticizer dispersion to a cohesive and elastic material. The phenomenon of torque overshoot in the study correlated with the presence of two different temperature zones found in the mixing process which undergone a significant increase from $45-55^{\circ} \mathrm{C}$ and showed a tendency to a plateau once the torque overshoot was exceeded.

The study on the physical properties and mechanical properties of polysaccharide/gluten - based bioplastic by L. S. Zárate - Ramírez, et al. was already discussed in previous chapters. According to the study, addition of polysaccharides obtained from either locust bean gum (LBG), methyl cellulose (MC), or carboxymethyl cellulose (CMC) only gave slight change to the glass transition temperature (Tg). All samples with mixtures of polysaccharide in the gluten bioplastic showed first temperature peak close to $0{ }^{\circ} \mathrm{C}$, whereas the second temperature peak was at near $60^{\circ} \mathrm{C} . .^{12}$ The occurrence of the first peak was due to plasticizer blend glass transition affected by some fractions of gluten isolate, ${ }^{17}$ while the occurrence of the second peak was caused by the glass transition of the plasticized gluten. ${ }^{18}$ Based on the obtained result, the polysaccharide acted as a filler occupying spaces within the bioplastic microstructure without giving any compatibilizing effect.

\section{Other Proteins - based Bioplastic}

Previous chapters already discussed the study of the physical properties and mechanical properties of pea protein isolate (PPI) based bioplastic by V. Perez, et al. The study also discussed its thermal properties. The glass transition temperature $(\mathrm{Tg})$ of the bioplastics experienced decrease in respect with greater content of glycerol as a plasticizing agent. In the case of pure PPI based bioplastic, the $\mathrm{Tg}$ was around $100{ }^{\circ} \mathrm{C} .{ }^{14}$ The decrease of $\mathrm{Tg}$ as the glycerol content increases was due to changes in the microstructure of the bioplastic. Utilization of temperature above $\mathrm{Tg}$ may result in more favourable processing due to higher mobility and lower viscosity in the biopolymer system.

The physical properties and mechanical properties of albumen protein (AP) and soy protein isolate (SPI) based bioplastic by $\mathrm{M}$. Félix, et al. was already discussed in previous chapters. According to the study on the result of Differential Scanning Calorimetry (DSC) testing, AP based bioplastic experienced glass transition at $94{ }^{\circ} \mathrm{C}$ with the second peak at $117^{\circ} \mathrm{C}$, while the SPI based bioplastic experienced glass transition at $90{ }^{\circ} \mathrm{C}$ after a single peak at $66^{\circ} \mathrm{C} .{ }^{15}$ The occurrence of both phenomenon was due to the fact that the thermal properties for both types of bioplastics have strong dependence on their moisture content. Another cause for the phenomenon of 
the SPI based bioplastic thermal properties was due to physical ageing phenomenon, which is a general phenomenon that occurs in under the glass transition temperature ( $\mathrm{Tg}$ ) of polymers with glassy or partial glassy properties, and is a form of the non-equilibrium nature of the glassy state. ${ }^{16}$ The phenomenon didn't occur in other samples utilizing glycerol mixture.

\section{Business Prospects}

\section{Business prospects based on Specific Energy Demand}

Specific energy demand is a term for the overall process needed in producing plastic materials. The overall process usually consists of (but not limited to) pre - processing, machine warm - up, and injection moulding process. The pre - processing step consists of mass of charge, drying temperature, and drying time. Low scale of production will be followed by bigger specific energy demand, whereas bigger scale in production is followed by lower specific energy demand.

The specific energy demand needed in producing starch blend and polylactic acid (PLA) based bioplastics in low scale is significantly lower than in producing Polypropylene (PP), with the specific energy demand value for both bioplastics are around $18.000 \mathrm{MJ} \mathrm{kg}^{-1}$, and around 27.500 $\mathrm{MJ} \mathrm{kg}^{-1}$ for PP. However, when compared in higher production scale, the required specific energy demand for both types of plastics are below $5000 \mathrm{MJ} \mathrm{kg}^{-1}$, although for bioplastics production the specific energy demand is still slightly lower than the petrochemical counterpart, ${ }^{20}$ which means that with same amount of energy, more bioplastics can be produced in order to supply the demands.

\section{Business prospects based on Green Environmental Support}

The term "Green environmental support" for materials is used when a material has a tendency to degrade naturally regardless of the condition of its environment. Bioplastics have several path of "end - of - life" after they are used: product reusing, mechanical recycling, chemical recycling, incineration, and disposal. In the case of disposal, composting and landfill are the options. ${ }^{21}$

Should one choose to dispose of bioplastic after use by landfill method, the bioplastic will not deposit to a waste build up since it decomposes over time in $\mathrm{CO}_{2}$, water, and even $\mathrm{CH}_{4}$. However, any improper disposal such as mixing biodegradable and non degradable wastes cannot be referred to the life cycle assessments. ${ }^{22} \mathrm{An}$ other thing for one to concern is that business in bioplastics will most likely face challenges such as, but not limited to: processing changes required for bioplastics, existence of new properties within bioplastics, and whether or not bioplastics can act as a substitute for the petrochemical counterparts..$^{23}$

\section{Conclusions}

The use of petrochemical plastic is slowly damaging the environment indirectly and will become a serious threat in the near future due to the time it takes to degrade. The appearance of bioplastic, a biodegradable plastic is already the solution of this unavoidable problem. Moreover, some bioplastic has the quality, even surpassing the petrochemical counterparts based on their mechanical and thermal properties. Taking a viewpoint from the business prospect, bioplastics excel petrochemical plastics in both specific energy demand and green environmental support.

\section{Conflicts of Interest}

There are no conflicts to declare.

\section{Acknowledgments}

The short review has received several suggestions from Mr. Joey Irvine, a bachelor student from Industrial Engineering of Universitas Indonesia.

\section{References}

1 A.A. Shah, F. Hasan, A. Hameed, S. Ahmed, Biological degradation of plastics: A comprehensive review, Biotechnology Advances, 2008, 26(June), 246-265.

2 Z. Kuruppalil, Green Plastics: An Emerging Alternative for Petroleum Based Plastics?, IAJC-ASEE International Conference, 2011, December, Paper 036, ENT202.

3 S. Spierling, C. Röttger, V. Venkatachalam, M. Mudersbach, C. Herrmann, H. Endres, Bio - based Plastics - A Building Block for the Circular Economy?, 25th CIRP Life Cycle Engineering (LCE) Conference, 2018, 69(May), 573-578.

4 D. Sagnelli, K.H. Hebelstrup, E. Leroy, A. Rolland-Sabaté, S. Guilois, J. J.K. Kirkensgaard, K. Mortensen, D. Lourdin, A. Blennow, Plant - crafted starches for bioplastic production, Carbohydrate Polymers, 2016, 152(July), 398-408.

5 J. Gonzalez-Gutierrez, P. Partal, M. Garcia-Morales, C. Gallegos, Development of highly - transparent protein/starch-based bioplastics, Bioresource Technology, 2009, 101(November), 20072013.

6 H.K. Adi, F.H. Ikhwan, H.A. Muliawan, M. Chalid, Polyurethanization temperature effect to the thermal behaviour of cellulose-fiber based hybrid polyurethane, Matec Web of Conferences, 2018, 159(March), 02005.

7 F.H. Ikhwan, S. Ilmiati, H.K. Adi, R. Arumsari, M. Chalid, Novel route of synthesis for cellulose fiber-based hybrid polyurethane, IOP Conference Series, 2017, 223(April), 012019.

8 L. Chen, X. Shou, N. Song, L. Shi, P. Ding, Cellulose/graphene bioplastic for thermal management: Enhanced isotropic thermally conductive property by three-dimensional interconnected graphene aerogel, Composites: Part A, 2017, 107(December), 189-196.

9 Q. Wang, J. Cai, L. Zhang, M. Xu, H. Cheng, C.C. Han, S. Kuga, R. Xiao, A bioplastic with high strength constructed from a cellulose hydrogel by changing the aggregated structure, Journal of Materials Chemistry A, 2013, 22(March), pp. 6678-6686.

10 P. Neha, Y. Pujita, A. anisha, M. Vyoma, An overview on the role of wheat gluten as a viable substitute for biodegradable plastics, Reviews in chemical engineering, 2014, 30(April), 421-430.

11 D. Gómez-Martínez, P. Partal, I. Martínez, C. Gallegos, Gluten based bioplastics with modified controlled - release and hydrophilic properties, Industrial Crops and Products, 2012, 43(August), 704-710. 
12 L.S. Zárate-Ramírez, A. Romero, C. Bengoechea, P. Partal, A. Guerrero, Thermo-mechanical and hydrophilic properties of polysaccharide/gluten-based plastics, Carbohydrate Polymers, 2014, 112(May), 24-31.

13 P.X. Qi, C. I, Onwulata, Physical properties, molecular structures, and protein quality of texturized whey protein isolate: Effect of extrusion moisture content, Journal of Dairy Science, 2011, 94(May), 2231-2244.

14 V. Perez, M. Felix, A. Romero, A. Guerrero, Characterization of pea protein-based bioplastics processed by injection moulding, Food and Bioproducts Processing, 2015, 97(December), 100108.

15 M. Félix, J.E. Martín-Alfonso, A. Romero, A. Guerrero, Development of albumen/soy biobased plastic materials processed by injection molding, Journal of Food Engineering, 2013, 125(October), 7-16.

16 L.C.E. Struik, Physical Aging in Amorphous Polymers and Other Materials ed. 1, Amsterdam: Elsevier, 1978.

17 L.S. Zárate-Ramírez, I. Martinez, A. Romero, C. Bengoechea, P. Partal, A. Guerrero, Wheat gluten-based materials plasticised with glycerol and water by thermoplastic mixing and thermomoulding, Journal of the Science of Food and Agriculture, 2011, 91(March), 625-633.
18 Y.I. Matveev, V.Y. Grinberg, V.B. Tolstoguzov, The plasticizing effect of water on proteins, polysaccharides and their mixtures. Glassy state of biopolymers, food and seeds, Food Hydrocolloids, 2000, 14(September), 425-437.

19 A.A. Sapega, J.A. Nicholas, D. Sokolow, A. Saraniti, The nature of torque 'overshoot' in Cybex isokinetic dynamometer, Medicine \& Science in Sports \& Exercise, 1982, 14(February), 368375.

20 C. Schulze, M. Juraschek, C. Hermann, S. Thiede, Energy analysis of bioplastic processing, Procedia CIRP, 2017, 61, 600-605.

21 S. Spierling, C. Röttger, V. Venkatachalam, M. Mudersbach, C. Hermann, Hans-Josef Endres, Bio - based Plastics - A Building Block for the Circular Economy?, Procedia CIRP, 2018, 69, 573578.

22 G. Sonnemann, S. Valdivia, Medellin Declaration on Marine Litter in Life Cycle Assessment and Management, The International Journal of Life Cycle Assessment, 2017, 22(October), 1637-1639.

23 A. lles, A.N. Martin, Expanding bioplastics production: sustainable business innovation in the chemical industry, Journal of Cleaner Production, 2012, 45(May), 38-49. 